\title{
Effects of nitrogen supply on the photosynthetic capacity of the hybrid citrus cultivar 'Huangguogan'
}

\author{
L. LIAO*, J.L. FU*, T.T. DONG*, X. QIU*, Y. RONG*, X.Y. LIU*, Z.X. DONG*, G.C. SUN*, \\ and Z.H. WANG ${ }^{* * *,+}$ \\ College of Horticulture, Sichuan Agricultural University, 611130 Chengdu, China* \\ Institute of Pomology and Olericulture, Sichuan Agricultural University, 611130 Chengdu, China**
}

\begin{abstract}
Pot experiments were conducted to determine the effects of nitrogen $(\mathrm{N})$ fertilization rate on the photosynthetic efficiency of 'Huangguogan' (Citrus reticulata $\times$ Citrus sinensis). We observed that plant growth increased with increasing N. Maximum values for parameters evaluated were recorded for an $\mathrm{N}$ addition rate of $120 \mathrm{~g}$ per year. Leaf chlorophyll content was positively correlated with the leaf $\mathrm{N}$ content. The relative reduction in photosynthetic rate $\left(P_{\mathrm{N}}\right)$ at high $\mathrm{N}(150$ and $180 \mathrm{~g}$ ) correlated with the parallel decreases in the leaf $\mathrm{N}$ content. Rubisco activity was positively correlated with the initial slope of the $P_{\mathrm{N}} / C_{\mathrm{i}}$ response curve.indicating that $\mathrm{N}$ supplement improved photosynthesis by enhancing carboxylation and $\mathrm{CO}_{2}$ diffusion, photosynthetic capacity increased with $\mathrm{N}$ supply up to $120 \mathrm{~g}$. Thereafter, the rate of increase declined with any further increase in $\mathrm{N}$ supply. These results provide a reference for a rational application of nitrogen fertilizer in orchards of 'Huangguogan'.
\end{abstract}

Additional key words: apparent $\mathrm{CO}_{2}$ /light-compensation point; diurnal respiration; maximum fluorescence; mesophyll conductance; steady-state fluorescence.

\section{Introduction}

Citrus is a commercially important genus of the Rutaceae. Many widely cultivated fruit species belong to this family (Hynniewta et al. 2014). 'Huangguogan' (Citrus reticulata $\times$ Citrus sinensis) is a new interspecific hybrid citrus cultivar in China; nonetheless, its cultivated area has been expanding rapidly in Southwestern China (Xiong et al. 2017).

Nitrogen is an essential nutrient for plant growth. In general, plants require more $\mathrm{N}$ than any other nutrient (Cruz et al. 2003). Several authors have proposed the need to determine the effect of $\mathrm{N}$ on citrus growth (Zekri and Obreza 2015, Sun et al. 2016). An appropriate N supply usually increases leaf $\mathrm{N}$ and Rubisco contents (Ookawa et al. 2004, Li et al. 2012). In contrast, $\mathrm{N}$ deficiency reduces chlorophyll (Chl) contents, electron transport rate (J), and the number of thylakoid components (Bondada and
Syvertsen 2003).

Photosynthesis is closely associated with citrus growth, development, yield, and fruit quality ( $\mathrm{Vu} 2005)$. Nitrogen is an important structural component of Chl and Rubisco. The contents of these two biomolecules are highly correlated with leaf $\mathrm{N}$. In theory, photosynthetic rate $\left(P_{\mathrm{N}}\right)$ should increase with leaf N (Makino et al. 1997), but Rubisco activity is limited by $\mathrm{CO}_{2}$ concentration at the chloroplast carboxylation sites $\left(C_{\mathrm{c}}\right)$ (Adachi et al. 2013), and a reduction in Rubisco lowers the $P_{\mathrm{N}}$ (Marcus et al. 2008). Although early studies suggested that $C_{\mathrm{c}}$ is limited mainly by stomatal conductance $\left(g_{\mathrm{s}}\right)$, it was recently reported that mesophyll conductance $\left(g_{\mathrm{m}}\right)$ has as strong effect on $C_{\mathrm{c}}$ as $g_{\mathrm{s}}$ (Evans et al. 2009, Xiong et al. 2015). Additionally, effects of $\mathrm{N}$ on $g_{\mathrm{m}}$ have been demonstrated (Buckley and Warren 2014, Xiong et al. 2015, Barbour and Kaiser 2016). Nutritional stress influences $g_{\mathrm{m}}$ as well as $\mathrm{g}_{\mathrm{s}}$; consequently, it also affects $P_{\mathrm{N}}$ (Yamori et al. 2011). The differential

$\overline{\text { Received }} 24$ June 2018, accepted 21 November 2018.

${ }^{+}$Corresponding author; phone/fax: 028-8629 1848, email: wangzhihui_siau@126.com

Abbreviations: $C_{\mathrm{a}}$ - atmospheric $\mathrm{CO}_{2}$ concentration; $C_{\mathrm{a}-\mathrm{c}}-$ ambient $\overline{\mathrm{CO}}_{2}$ concentration in the cuvette; $C_{\mathrm{c}}-\mathrm{CO}_{2}$ concentration at the carboxylation sites inside the chloroplast; $\mathrm{CE}$ - carboxylation efficiency; $\mathrm{CE}_{\mathrm{PN} / \mathrm{Cc}}-$ initial slope of the $P_{\mathrm{N}} / C_{\mathrm{c}}$ response curve; $\mathrm{CE}_{\mathrm{PN} / \mathrm{Ci}}-$ initial slope of the $P_{\mathrm{N}} / C_{\mathrm{i}}$ response curve; Chl - chlorophyll; $C_{\mathrm{i}}$ - intercellular $\mathrm{CO}_{2}$ concentration; $C_{\mathrm{i}}^{*}$ - apparent $\mathrm{CO}_{2}$ light-compensation point; $\mathrm{F}_{\mathrm{s}}$ - steady-state fluorescence; $\mathrm{F}_{\mathrm{m}}{ }^{\prime}$ - maximum fluorescence; $g_{\mathrm{m}}$ - mesophyll conductance; $g_{\mathrm{s}}$ - stomatal conductance; $\mathrm{J}$ - rate of electron transport; $\mathrm{J}_{\max }-\mathrm{RuBP}$ regeneration supported by electron transport; $P_{\mathrm{N}}-$ photosynthetic rate; $R_{\mathrm{D}}-$ day respiration; RuBP ribulose-1,5-bisphosphate; TPU - triose phosphate use; $\mathrm{V}_{\mathrm{c}}$ - carboxylation rate; $\mathrm{V}_{\text {cmax }}$ - maximum carboxylation rate limited by Rubisco; $\mathrm{V}_{\mathrm{o}}$ - oxygenation rate; $\alpha$ - apparent quantum yield; $\Phi$ - ratio of $\mathrm{V}_{\mathrm{o}}$ to $\mathrm{V}_{\mathrm{c}}$; $\Phi_{\mathrm{PSII}}$ - actual photochemical efficiency of PSII; $\Gamma^{*}-\mathrm{CO}_{2}$-compensation point in the absence of respiration.

Acknowledgements: This work was supported by the Foundation of the Science and Technology Department of Sichuan Province, China (Grant No. 2011NZ0034), the Foundation of Education Department of Sichuan Province, China (Grant No. 2013SZX0054), and the Social Practice and Technology Service Foundation for the graduate students of Sichuan Agricultural University (Grant No. ACT201304). 
responses of stomatal morphology to $\mathrm{N}$ application rate have also been studied (Yan et al. 2012). Further, it has been shown that plant $\mathrm{N}$ content is highly and positively correlated with $P_{\mathrm{N}}$, and that it regulates stomatal traits $(\mathrm{Li}$ et al. 2003), and stomatal density, so that gas diffusion resistance decreases with increasing stomatal density (Chen et al. 1995).

In the present study, seedlings of cultivar 'Huangguogan' were grown in a pot experiment and subjected to seven different $\mathrm{N}$ concentrations. The effects of $\mathrm{N}$ supplementation on the following parameters were evaluated: (1) leaf N and photosynthetic pigments; (2) Rubisco content and activity; and (3) gas-exchange parameters and Chl fluorescence.

\section{Materials and methods}

Plant material and $\mathbf{N}$ treatments: One-year-old potted seedlings of the hybrid citrus cultivar 'Huangguogan' were grafted onto trifoliate orange [Poncirus trifoliata (L.) Raf] obtained from the 'Huangguogan' demonstration nursery stock in September 2015. Seedlings were grown under ambient conditions at the campus of Sichuan Agricultural University in Chengdu, China. The annual average temperature was $<20^{\circ} \mathrm{C}$ and the annual rainfall was $760 \mathrm{~mm}$. Seedlings with uniform leaf area and $\mathrm{N}$ content were grown in 10-L pots in order to avoid any restrictions of root growth. The potting medium was a loamy soil (40\% sandy loam, $30 \%$ silt, $20 \%$ rotten leaf soil, and 10\% chicken manure). The main physicochemical properties of this medium were: $19.58 \mathrm{~g}$ (organic matter) $\mathrm{kg}^{-1}, 0.93 \mathrm{mg}$ (total $\mathrm{N}$ ) $\mathrm{kg}^{-1}$, $95.33 \mathrm{mg}\left(\right.$ hydrolytic N) $\mathrm{kg}^{-1}, 52.48 \mathrm{mg}$ (available $\left.\mathrm{P}\right) \mathrm{kg}^{-1}$, and $54.42 \mathrm{mg}$ (available K) $\mathrm{kg}^{-1}$. Seedlings were acclimated to their new location for six months, during which they were subject to standard citrus management.

The experiment was laid in a completely randomized design with seven treatments $\left(\mathrm{N}_{1}-\mathrm{N}_{7}\right)$ and five replicates, each consisting of one tree, for a total of 35 plants which were all fertilized with $60 \mathrm{~g}$ of phosphorus $\left[\mathrm{CaP}_{2} \mathrm{H}_{4} \mathrm{O}_{8}\right.$; $\left.\mathrm{P}_{2} \mathrm{O}_{5} \geq 12 \%\right]$ and $120 \mathrm{~g}$ of potassium $\left[\mathrm{K}_{2} \mathrm{SO}_{4} ; \mathrm{K}_{2} \mathrm{O} \geq\right.$ $50.0 \%]$. Nitrogen $\left[\mathrm{CO}\left(\mathrm{NH}_{2}\right)_{2} ; \mathrm{N} \geq 46.67 \%\right]$ was applied at $0\left(\mathrm{~N}_{1}\right), 30\left(\mathrm{~N}_{2}\right), 60\left(\mathrm{~N}_{3}\right), 90\left(\mathrm{~N}_{4}\right), 120\left(\mathrm{~N}_{5}\right), 150\left(\mathrm{~N}_{6}\right)$, and $180\left(\mathrm{~N}_{7}\right)$ g per year. Fertilizers were applied at germination $(G)$, physiological fruit dropping $(P)$, young fruit expansion $(\mathrm{Y})$, and color change $(\mathrm{C})$. The G:P:Y:C ratios were $40: 10: 40: 10 \%$ for the $\mathrm{CO}\left(\mathrm{NH}_{2}\right)_{2}$ application model, 30:10:40:20\% for the $\mathrm{CaP}_{2} \mathrm{H}_{4} \mathrm{O}_{8}$ application model, and 20:30:40:10\% for the $\mathrm{K}_{2} \mathrm{SO}_{4}$ application model (Table 1). All trees were frequently irrigated to ensure nonlimiting water availability. They received normal horticultural care for pest and disease control. The whole experiment was conducted for one year under natural conditions. Five plants per the experimental group were marked and used to measure photosynthetic parameters and $\mathrm{Chl}$ fluorescence. The third to fifth healthy functional leaves on the southern side of the crown were sampled to determine the $\mathrm{Chl}$ content and stomatal opening. Intermediate leaves were excised and ground under liquid nitrogen to determine photosynthesis-related enzyme activities.
Gas exchange and fluorescence: All measurements were taken with a $\mathrm{Li}$-Cor 6400 portable photosynthesis system (Li-Cor Inc., Lincoln, NE, USA) on mature current-year leaves from five plants per treatment over $3 \mathrm{~d}$ in March 2017. The rates of light-saturated photosynthesis were measured from 09:00 to 11:30 h. The leaf chamber conditions were as follows: PPFD of 1,600 $\mu \mathrm{mol} \mathrm{m} \mathrm{m}^{-2} \mathrm{~s}^{-1}$, relative humidity of $60 \pm 3 \%, \mathrm{CO}_{2}$ concentration in the cuvette $\left(C_{\mathrm{a}-\mathrm{c}}\right)$ of $400 \pm 2 \mu \mathrm{mol}\left(\mathrm{CO}_{2}\right) \mathrm{mol}^{-1}$, and leaf temperature of $29 \pm 0.2^{\circ} \mathrm{C}$. Data were recorded after steady state was reached $(\sim 15 \mathrm{~min})$. The sampled third to fifth healthy functional leaves on the southern side of the crown were labeled and their leaf areas calculated based on the labeled areas. Subsequent gasexchange measurements were conducted on these labeled leaves. After gas-exchange measurements, lightresponse curves were plotted. Leaf temperature, relative humidity, and $C_{\mathrm{a}-\mathrm{c}}$ were maintained as described above. Before measurements, sampled leaves were acclimated in the leaf chamber at PPFD of $1,600 \mu \mathrm{mol} \mathrm{m} \mathrm{m}^{-2} \mathrm{~s}^{-1}$ for 10-15 min for full photosynthetic activation; PPFD was then controlled at 2,$300 ; 2,000 ; 1,800 ; 1,600 ; 1,400$; 1,$200 ; 1,000 ; 800,600,400,200,150,100,75,50$, and $0 \mu \mathrm{mol} \mathrm{m} \mathrm{m}^{-2} \mathrm{~s}^{-1}$. The corresponding apparent quantum yields $(\alpha)$ were calculated as the slopes of the light-response curves when PPFD in the leaf cuvette was controlled at $150,100,75$, and $50 \mu \mathrm{mol} \mathrm{m}{ }^{-2} \mathrm{~s}^{-1}$.

Simultaneous $P_{\mathrm{N}} / C_{\mathrm{i}}$ curve and Chl fluorescence measurements were conducted on light-adjusted leaves using a $\mathrm{Li}$-Cor 6400 infrared gas analyzer (Li-Cor Inc., Lincoln, NE, USA). Leaf temperature, relative humidity, and PPFD were controlled as described above. Before measurements, leaves were placed in the leaf chamber under PPFD of $1,600 \mu \mathrm{mol} \mathrm{m}^{-2} \mathrm{~s}^{-1}, \mathrm{CO}_{2}$ was maintained at $400 \mu \mathrm{mol} \mathrm{mol}^{-1}$ by running a $\mathrm{CO}_{2}$ mixer for $10-15 \mathrm{~min} ; \mathrm{CO}_{2}$ was controlled at $400,300,200,100,50,400,600,800 ; 1,000 ; 1,300$; 1,600; and 2,000 $\mu \mathrm{mol}\left(\mathrm{CO}_{2}\right) \mathrm{mol}^{-1}$. Gas exchange, steadystate fluorescence $\left(\mathrm{F}_{\mathrm{s}}\right)$, and maximum fluorescence $\left(\mathrm{F}_{\mathrm{m}}{ }^{\prime}\right)$ were recorded after reaching the steady state. $\mathrm{F}_{\mathrm{m}}{ }^{\prime}$ at each $\mathrm{CO}_{2}$ concentration was measured with a 0.8 -s saturating light pulse $\left[\sim 8,000 \mu \mathrm{mol}\right.$ (photon) $\left.\mathrm{m}^{-2} \mathrm{~s}^{-1}\right] . \mathrm{F}_{\mathrm{s}}$ and $\mathrm{F}_{\mathrm{m}}{ }^{\prime}$ at $1,600 \mu \mathrm{mol}$ (photon) $\mathrm{m}^{-2} \mathrm{~s}^{-1}$ and $400 \mu \mathrm{mol}\left(\mathrm{CO}_{2}\right) \mathrm{mol}^{-1}$ were used to calculate $\left(\mathrm{F}_{\mathrm{m}}{ }^{\prime}-\mathrm{F}_{\mathrm{s}}\right) / \mathrm{F}_{\mathrm{m}}{ }^{\prime}$. Carboxylation efficiency $(\mathrm{CE})$ for each $\mathrm{N}$ treatment was calculated as the initial slope of the $P_{\mathrm{N}} / C_{\mathrm{i}}$ curve when $\mathrm{CO}_{2}$ was $<200 \mu \mathrm{mol}\left(\mathrm{CO}_{2}\right)$ $\mathrm{mol}^{-1}$.

Leakage was inevitable while the leaves were attached to the leaf chamber. Therefore, the same measurements were used to minimize the effects of leakage on $P_{\mathrm{N}}$ and $C_{\mathrm{i}}$ as previously described (Flexas and Ribas-Carbó 2007, Li et al. 2009).

Diurnal respiration $\left(R_{\mathrm{D}}\right)$ and apparent $\mathrm{CO}_{2}$ lightcompensation point $\left(\boldsymbol{C}_{\mathrm{i}}^{*}\right): R_{\mathrm{D}}$ and $C_{\mathrm{i}}^{*}$ were determined between 0:00 and 04:00 h by the Laĭsk method (Laĭsk 1977), using the same leaves used for measurements of $P_{\mathrm{N}} / C_{\mathrm{i}}$ and light-response curves (Guo et al. 2007). Briefly, $P_{\mathrm{N}} / C_{\mathrm{i}}$ curves were plotted over the linear portion of the dose-response curve $[25,50,100$, and $\left.150 \mu \mathrm{mol}\left(\mathrm{CO}_{2}\right) \mathrm{mol}^{-1}\right]$ under three PPFD levels $(150,300$, 
Table 1. Amount of fertilizer applied during growth of 'Huangguogan' citrus plants. $\mathrm{N}_{1}, \mathrm{~N}_{2}, \mathrm{~N}_{3}, \mathrm{~N}_{4}, \mathrm{~N}_{5}, \mathrm{~N}_{6}$, and $\mathrm{N}_{7}$ stand for 0,30 , 60, $90,120,150$, and $180 \mathrm{~g}(\mathrm{~N})$ year $^{-1}$, respectively. Fertilizers were applied at germination $(\mathrm{G})$, physiological fruit dropping $(\mathrm{P})$, young fruit expansion (Y), and color change (C).

\begin{tabular}{|c|c|c|c|c|}
\hline Treatment & Period & $\begin{array}{l}\mathrm{CO}\left(\mathrm{NH}_{2}\right)_{2}(\mathrm{~N} \geq 46.67 \%) \\
\text { [g per plant] }\end{array}$ & $\begin{array}{l}\mathrm{CaP}_{2} \mathrm{H}_{4} \mathrm{O}_{8}\left(\mathrm{P}_{2} \mathrm{O}_{5} \geq 12 \%\right) \\
\text { [g per plant] }\end{array}$ & $\begin{array}{l}\mathrm{K}_{2} \mathrm{SO}_{4}\left(\mathrm{~K}_{2} \mathrm{O} \geq 50.0 \%\right) \\
{[\text { g per plant] }}\end{array}$ \\
\hline \multirow{4}{*}{$\mathrm{N}_{1}$} & $\mathrm{G}$ & 0 & 18 & 24 \\
\hline & $\mathrm{P}$ & 0 & 6 & 36 \\
\hline & $\mathrm{Y}$ & 0 & 24 & 48 \\
\hline & $\mathrm{C}$ & 0 & 12 & 12 \\
\hline \multirow{4}{*}{$\mathrm{N}_{2}$} & G & 12 & 18 & 24 \\
\hline & $\mathrm{P}$ & 3 & 6 & 36 \\
\hline & $\mathrm{Y}$ & 12 & 24 & 48 \\
\hline & $\mathrm{C}$ & 3 & 12 & 12 \\
\hline \multirow[t]{4}{*}{$\mathrm{N}_{3}$} & $\mathrm{G}$ & 24 & 18 & 24 \\
\hline & $\mathrm{P}$ & 6 & 6 & 36 \\
\hline & $\mathrm{Y}$ & 24 & 24 & 48 \\
\hline & $\mathrm{C}$ & 6 & 12 & 12 \\
\hline \multirow[t]{4}{*}{$\mathrm{N}_{4}$} & G & 36 & 18 & 24 \\
\hline & $\mathrm{P}$ & 9 & 6 & 36 \\
\hline & $\mathrm{Y}$ & 36 & 24 & 48 \\
\hline & $\mathrm{C}$ & 9 & 12 & 12 \\
\hline \multirow[t]{4}{*}{$\mathrm{N}_{5}$} & G & 48 & 18 & 24 \\
\hline & $\mathrm{P}$ & 12 & 6 & 36 \\
\hline & $\mathrm{Y}$ & 48 & 24 & 48 \\
\hline & $\mathrm{C}$ & 12 & 12 & 12 \\
\hline \multirow[t]{4}{*}{$\mathrm{N}_{6}$} & G & 60 & 18 & 24 \\
\hline & $\mathrm{P}$ & 15 & 6 & 36 \\
\hline & $\mathrm{Y}$ & 60 & 24 & 48 \\
\hline & $\mathrm{C}$ & 15 & 12 & 12 \\
\hline \multirow[t]{4}{*}{$\mathrm{N}_{7}$} & G & 72 & 18 & 24 \\
\hline & $\mathrm{P}$ & 18 & 6 & 36 \\
\hline & $\mathrm{Y}$ & 72 & 24 & 48 \\
\hline & $\mathrm{C}$ & 18 & 12 & 12 \\
\hline
\end{tabular}

and $600 \mu \mathrm{mol} \mathrm{m} \mathrm{m}^{-2} \mathrm{~s}^{-1}$. The curves intersected where $P_{\mathrm{N}}$ was the same for all PPFD tested. Therefore, $P_{\mathrm{N}}$ represented $R_{\mathrm{D}}$ and $C_{\mathrm{i}}$ represented $C_{\mathrm{i}}^{*}$.

Rubisco activity and content, $\mathrm{Chl}$ and leaf $\mathrm{N}$ content: Leaf samples were ground to a fine powder in liquid nitrogen and Rubisco activity and content were measured with a Plant RuBisCO activity ELISA Kit and a Plant RuBisCO content ELISA Kit, respectively (Shanghai BOYE Biology Science \& Technology Co. Ltd., Shanghai, China), according to the instructions of the manufacturer.

Acetone and anhydrous alcohol were mixed in a 1:1 volumetric ratio. Leaves were cut into $1-\mathrm{mm}$ pieces and combined. Then, $0.5-\mathrm{g}$ samples were placed in test tubes containing $25 \mathrm{~mL}$ of extraction mixture, sealed, and extracted in darkness for $24 \mathrm{~h}$ until the leaves were totally bleached. A UV spectrophotometer (UV-1600, Shimadzu Corp., Kyoto, Japan) was used to measure the absorbances of Chl $a, \mathrm{Chl} b$, and carotenoids at 665,649 , and $470 \mathrm{~nm}$, respectively. Pigment concentrations were calculated with the Arnon formula (Esteban et al. 2017).

Total $\mathrm{N}$ was determined by the Kjeldahl method. Whole labeled leaves were oven-dried for $30 \mathrm{~min}$ at $105^{\circ} \mathrm{C}$ and then to constant mass at $70^{\circ} \mathrm{C}$. The leaves were digested with $\mathrm{H}_{2} \mathrm{SO}_{4}-\mathrm{H}_{2} \mathrm{O}_{2}$ at $260-270^{\circ} \mathrm{C}$. An automatic Kjeldahl nitrogen determination apparatus ( ATN-300, Shanghai Drawell Scientific Instrument Co. Ltd., Shanghai, China) was used to determine total $\mathrm{N}$.

Stomatal morphology: Thin layers of nail polish were brushed onto the leaf blade surfaces. When the nail polish was dry, transparent adhesive tape was used to remove it from the leaf blade. It was then inspected under an Olympus BX51 microscope (Guangzhou Ming-Mei Technology Co. Ltd., Guangdong, China). Stomatal densities were determined at $400 \times$ magnification. Stomatal size and opening were observed at $1000 \times$ magnification. Stomatal size was determined with a microscope stage micrometer (Jiang et al. 2011). 
Models: The actual photochemical efficiency of PSII ( $\left.\Phi_{\mathrm{PSII}}\right)$ was calculated as follows:

$\Phi_{\text {PSII }}=\left(\mathrm{F}_{\mathrm{m}}{ }^{\prime}-\mathrm{F}_{\mathrm{s}}\right) / \mathrm{F}_{\mathrm{m}}$

The electron transport rate $(\mathrm{J})$ was calculated as follows:

$\mathrm{J}=\Phi_{\mathrm{PSII}} \times \mathrm{PPFD} \times \alpha \times \beta$

where $\alpha$ is the leaf absorbance and $\beta$ is the partitioning of the absorbed quanta between PSI and PSII. In this study, $\alpha$ and $\beta$ were assumed to be 0.85 and 0.5 , respectively (Albertsson 2001).

$\mathrm{V}_{\text {cmax }}$ was $8 \times 2.5 \times 10^{6 / 550000}(=36.36)$ times the Rubisco content $\left(\mathrm{g} \mathrm{m}^{-2}\right)$. $\mathrm{J}_{\text {cmax }}$ was determined from $\mathrm{J}_{\max }$ as follows (Farquhar et al. 1980):

$\mathrm{J}_{\mathrm{cmax}}=\mathrm{J}_{\max } /(4+4 \Phi)$

where $\Phi$ is the ratio of the oxygenation rate $\left(V_{0}\right)$ to the carboxylation rate $\left(\mathrm{V}_{\mathrm{c}}\right) . \Phi$ was determined according to Sharkey (1988):

$\Phi=\mathrm{V}_{\mathrm{o}} / \mathrm{V}_{\mathrm{c}}=2 \Gamma^{*} / C_{\mathrm{c}}$

$C_{\mathrm{c}}$ and $g_{\mathrm{m}}$ were determined according to the variable $\mathrm{J}$ method (Harley et al. 1992) as follows:

$C_{c}=\frac{\Gamma^{*}\left(\mathrm{~J}+8\left(P_{\mathrm{N}}+R_{\mathrm{D}}\right)\right)}{\mathrm{J}-4\left(P_{\mathrm{N}}+R_{\mathrm{D}}\right)}$

$g_{\mathrm{m}}=P_{\mathrm{N}} /\left(C_{\mathrm{i}}-C_{\mathrm{c}}\right)$

$\Gamma^{*}\left(\mathrm{CO}_{2}\right.$-compensation point in the absence of respiration) was calculated as follows (Harley et al. 1992):

$\Gamma^{*}=C_{\mathrm{i}}^{*}+R_{\mathrm{D}} / g_{\mathrm{m}}$

$P_{\mathrm{N}}$ was calculated as follows (Farquhar et al. 1980):

$$
P_{\mathrm{N}}=\frac{\mathrm{V}_{\mathrm{cmax}} C_{\mathrm{c}}}{C_{\mathrm{c}}+\mathrm{K}_{\mathrm{c}}\left(1+O / \mathrm{K}_{\mathrm{o}}\right)}\left(1-\frac{\Gamma^{*}}{C_{\mathrm{c}}}\right)-R_{\mathrm{D}}
$$

where $K_{\mathrm{c}}$ and $K_{\mathrm{o}}$ are the Michaelis-Menten constants for $\mathrm{CO}_{2}$ and $\mathrm{O}_{2}$, and $O$ is atmospheric $\mathrm{O}_{2}$ concentration.

Statistical analysis: Simple linear regressions were run in Microsoft Excel 2010. One-way analysis of variance (ANOVA) was run in SPSS v. 23.0 (IBM Corp., Armonk, NY, USA) to assess the significance of the differences between treatments for each parameter. Means were compared by the least significant difference $(L S D)$ multiple comparison test $(P<0.05)$.

\section{Results}

Effects of $\mathbf{N}$ on 'Huangguogan' leaf biochemistry parameters: Relative to the control $\left(\mathrm{N}_{1}\right)$, leaf $\mathrm{N}$ progressively increased in $\mathrm{N}_{2}, \mathrm{~N}_{3}, \mathrm{~N}_{4}$, and $\mathrm{N}_{5}$, but declined in $\mathrm{N}_{6}$ and $\mathrm{N}_{7}$ (Fig. 1B). Similarly, individual leaf area progressively increased in $\mathrm{N}_{2}, \mathrm{~N}_{3}$, and $\mathrm{N}_{4}$, but decreased in $\mathrm{N}_{5}, \mathrm{~N}_{6}$, and $\mathrm{N}_{7}$ (Fig. 1A). Concomitantly, the Rubisco content and activity progressively increased in $\mathrm{N}_{2}, \mathrm{~N}_{3}, \mathrm{~N}_{4}$, and $\mathrm{N}_{5}$ but were reduced in the $\mathrm{N}_{6}$ and $\mathrm{N}_{7}$ (Fig. $1 G, H$ ). Similarly, the carotenoid content and $\mathrm{Chl} a, \mathrm{Chl} b$, and total Chl were enhanced in $\mathrm{N}_{2}, \mathrm{~N}_{3}, \mathrm{~N}_{4}$, and $\mathrm{N}_{5}$, but decreased in $\mathrm{N}_{5}, \mathrm{~N}_{6}$, and $\mathrm{N}_{7}$ (Fig. $1 C-F$ ). In all cases, differences between treatments were significant. Overall performance of the measured indices was best in plants under $\mathrm{N}_{5}$, compared to controls $\left(\mathrm{N}_{1}\right)$. The Chl content was $15.6 \%$ higher in $\mathrm{N}_{5}$ than that in $\mathrm{N}_{1}$. The leaf $\mathrm{N}$ content was $177 \%$ higher in $\mathrm{N}_{5}$ than that in $\mathrm{N}_{1}$, while Rubisco content in $\mathrm{N}_{5}$ was only $37.4 \%$ higher than that in $\mathrm{N}_{1}$.

Effects of $\mathbf{N}$ on leaf gas-exchange parameters: Carboxylation efficiency (CE) increased with increasing $\mathrm{N}$ supply until saturation, but then decreased at higher (excessive) $\mathrm{N}$ fertilization doses. Differences between $\mathrm{N}$ treatments in terms of $\mathrm{CE}$ and $\alpha$ were significant (Fig. $2 A-C$ ). Intercellular $\mathrm{CO}_{2}$ dose-response curves showed that the maximum light-saturated $\mathrm{CO}_{2}$ assimilation rate $\left(P_{\mathrm{Nmax}}\right)$, increased with $\mathrm{N}$ supply up to $\mathrm{N}_{5}$, where it peaked. $P_{\mathrm{Nmax}}$ were $\sim 22.61,21.23,26.54,26.55,28.29,23.58$, and $19.70 \mu \mathrm{mol}\left(\mathrm{CO}_{2}\right) \mathrm{m}^{-2} \mathrm{~s}^{-1}$ for $\mathrm{N}_{1}, \mathrm{~N}_{2}, \mathrm{~N}_{3}, \mathrm{~N}_{4}, \mathrm{~N}_{5}, \mathrm{~N}_{6}$, and $\mathrm{N}_{7}$, respectively (Fig. 3A). The initial slope of the $P_{\mathrm{N}} / C_{\mathrm{i}}$

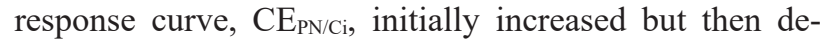
creased with increasing $\mathrm{N}$ supply. According to the estimated chloroplast $\mathrm{CO}_{2}$ dose-response curves, there were significant differences between $\mathrm{N}$ concentrations in terms of the initial slope of the $P_{\mathrm{N}} / C_{\mathrm{c}}$ response curve, $\mathrm{CE}_{\mathrm{PN} / \mathrm{Cc}}$ (Fig. 2A,B). Similarly, there were significant differences between the $\mathrm{N}$ treatments in terms of $\mathrm{V}_{\mathrm{cmax}}, \mathrm{J}_{\max }, \mathrm{J}_{\mathrm{cmax}}$, and TPU, all of which increased with increasing $\mathrm{N}$ up to peak values under $\mathrm{N}_{5}$. Thereafter, they all decreased with further increasing $\mathrm{N}$ supply (Fig. $2 D-G$ ).

Effects of leaf $\mathrm{N}$ content on $\boldsymbol{R}_{\mathrm{D}}, \boldsymbol{\Gamma}^{*}, \boldsymbol{C}_{\mathrm{c}}$, and $\boldsymbol{g}_{\mathrm{m}}$ : The value of $P_{\mathrm{N}}$ was significantly higher for $\mathrm{N}_{5}$ than for any other treatment. $R_{\mathrm{D}}, g_{\mathrm{s}}$, and $g_{\mathrm{m}}$ also increased with $\mathrm{N}$ supply and reached maxima under $\mathrm{N}_{5}$ (Fig. $3 A-D$ ). These indices all showed similar variation patterns in response to increasing $\mathrm{N}$ as those described above for other variables. In contrast, $C_{\mathrm{i}}, C_{\mathrm{c}}, C_{\mathrm{i}}^{*}$, and $\Gamma^{*}$ all tended to decrease with increasing $\mathrm{N}$ supply up to $\mathrm{N}_{5}$ (Fig. $3 E-H$ ).

Responses of gas exchange to rapid changes in $\mathrm{CO}_{2}$ concentration: Fast intercellular $\mathrm{CO}_{2}$-response $\left(P_{\mathrm{N}} / C_{\mathrm{i}}\right)$ curves were analyzed for the seven $\mathrm{N}$ treatments under evaluation here (Fig. $4 C$ ). $\mathrm{CE}_{\mathrm{PN} / \mathrm{Ci}}$ increased with $\mathrm{N}$, reached a maximum at $\mathrm{N}_{5}$, and decreased thereafter (Fig. $2 A$ ). The values for $P_{\mathrm{N}}$ were 8.8, 13.61, and $6.54 \mu \mathrm{mol}\left(\mathrm{CO}_{2}\right) \mathrm{m}^{-2} \mathrm{~s}^{-1}$ for $\mathrm{N}_{1}$, $\mathrm{N}_{5}$, and $\mathrm{N}_{7}$, respectively (Fig. $1 I$ ). Both, $g_{\mathrm{s}}$ and $g_{\mathrm{m}}$ decreased with increasing $C_{\mathrm{i}}$ under $\mathrm{N}$ supplementation (Fig. 4A,B).

Effects of different $\mathbf{N}$ concentrations on photosynthetic light-response curves: In all $\mathrm{N}$ treatments, $P_{\mathrm{N}}$ rapidly increased to a maximum rate with increasing PPFD. However, as PPFD continued to increase, $P_{\mathrm{N}}$ was stabilized under $\mathrm{N}_{2}, \mathrm{~N}_{3}, \mathrm{~N}_{4}$, and $\mathrm{N}_{5}$, but then rapidly decreased under $\mathrm{N}_{1}, \mathrm{~N}_{6}$, and $\mathrm{N}_{7}$. Moreover, the PPFD levels inducing maximum $P_{\mathrm{N}}$ significantly differed between the $\mathrm{N}$ treatments (Fig. 5).

Effects of $\mathrm{N}$ on stomatal size and density in leaves of 

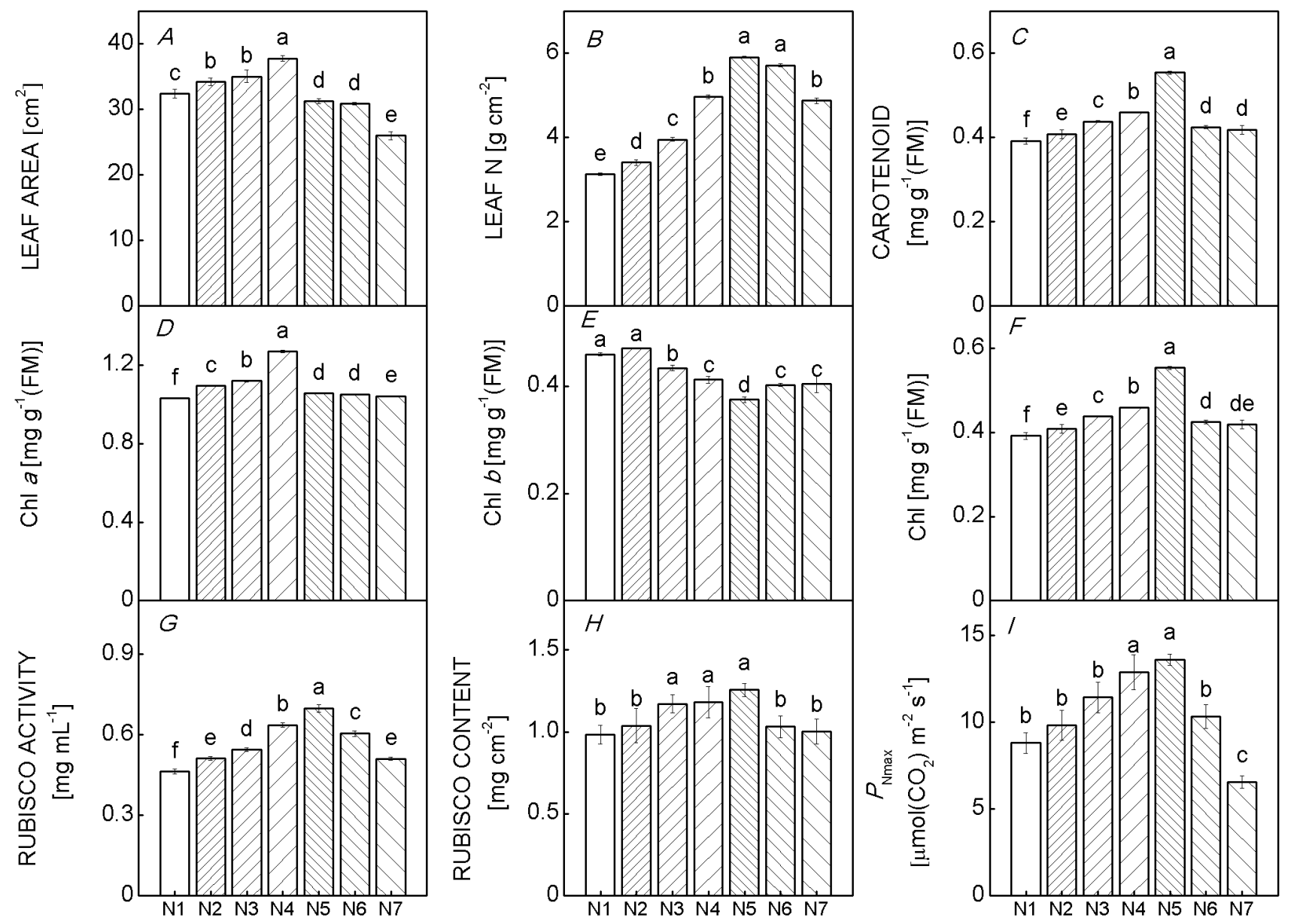

Fig. 1. Effects of different $\mathrm{N}$ levels on individual leaf area $(A)$, leaf $\mathrm{N}$ content $(B)$, carotenoid content $(C)$, leaf Chl $a(D)$, Chl $b(E)$, and total Chl content $(F)$, Rubisco activity $(G)$, Rubisco content $(H)$, and maximum light-saturated $\mathrm{CO}_{2}$ assimilation rate $\left(P_{\mathrm{Nmax}}\right)(I)$ of 'Huangguogan' citrus plants. Data are means \pm SD of five replications. Significant differences $(P<5 \%)$ between treatments are indicated by different letters. $\mathrm{N}_{1}, \mathrm{~N}_{2}, \mathrm{~N}_{3}, \mathrm{~N}_{4}, \mathrm{~N}_{5}, \mathrm{~N}_{6}$, and $\mathrm{N}_{7}$ stand for $0,30,60,90,120,150$, and $180 \mathrm{~g}(\mathrm{~N})$ year ${ }^{-1}$, respectively.

cultivar 'Huangguogan': Stomatal density significantly decreased, while stomatal length slightly increased and stomatal width slightly decreased with increasing $\mathrm{N}$ supply (Table 2; Fig. 1S, supplement).

\section{Discussion}

Photosynthetic rate in leaves of hybrid citrus cultivar 'Huangguogan' is related to $N$ supplement and leaf N content: Positive correlations between leaf $\mathrm{N}$ or $\mathrm{N}$ fertilization rate and $\mathrm{Chl}$ content have been documented for numerous plant species (Chang and Robison 2003, Mauromicale et al. 2006, Nageswara Rao et al. 2010). In this experiment, we observed that plant growth increased with increasing $\mathrm{N}$ fertilization. The beneficial effects of $\mathrm{N}$ supply increase include the increased leaf $\mathrm{N}$ content, leaf area, and Chl content. Nevertheless, these three parameters tended to decrease, relative to controls, at the higher $\mathrm{N}$ concentrations tested (150 and $180 \mathrm{~g})$. Leaf Chl content was positively correlated with the leaf $\mathrm{N}$ content. There is a clear linear relationship between leaf $\mathrm{N}$ content and light-saturated photosynthetic rate (Yamori et al.
2011, Barbet-Massin et al. 2015, Xiong et al. 2015). Photosynthetic pigment contents are important indicators of senescence (Brown et al. 1991). Here, we found that $P_{\mathrm{N}}$ progressively increased in plants under $\mathrm{N}_{2}, \mathrm{~N}_{3}, \mathrm{~N}_{4}$, and $\mathrm{N}_{5}$, but decreased in plants under $\mathrm{N}_{6}$ and $\mathrm{N}_{7}$, compared with the control plants $\left(\mathrm{N}_{1}\right)$. The relative reduction in $P_{\mathrm{N}}$ at high $\mathrm{N}$ (150 and $180 \mathrm{~g}$ ) might be correlated with the parallel decreases in the leaf $\mathrm{N}$ content and photosynthetic pigment biosynthesis.

In $\mathrm{C}_{3}$ plants, $P_{\mathrm{N}}$ is limited by Rubisco carboxylation capacity and/or $C_{\mathrm{c}}$ (von Caemmerer and Evans 2010). Here, we recorded that Rubisco content and activity changed in parallel with $P_{\mathrm{N}}$ at increasing $\mathrm{N}$ application rates. It was proposed that Rubisco activity in leaves with a high $\mathrm{N}$ content was greater than that in leaves with low $\mathrm{N}$ content ( $\mathrm{Li}$ et al. 2012). Trends in the changes of $C_{\mathrm{i}}$ and $C_{\mathrm{c}}$ were consistent with these findings; indeed, $C_{\mathrm{i}}$ is the product of the cooperation of $C_{\mathrm{a}}, g_{\mathrm{s}}, g_{\mathrm{m}}$, and $P_{\mathrm{N}}$. Increases in $C_{\mathrm{a}}, g_{\mathrm{s}}$, and $g_{\mathrm{m}}$ and decreases in $P_{\mathrm{N}}$ may increase $C_{\mathrm{i}}$. On the other hand, $C_{\mathrm{a}}$ remained stable in the present study. Therefore, $C_{\mathrm{i}}$ was determined from $g_{\mathrm{s}}$ and $P_{\mathrm{N}}$. Only when $g_{\mathrm{m}}$ is small enough, it significantly affects $C_{\mathrm{i}}$. We found 


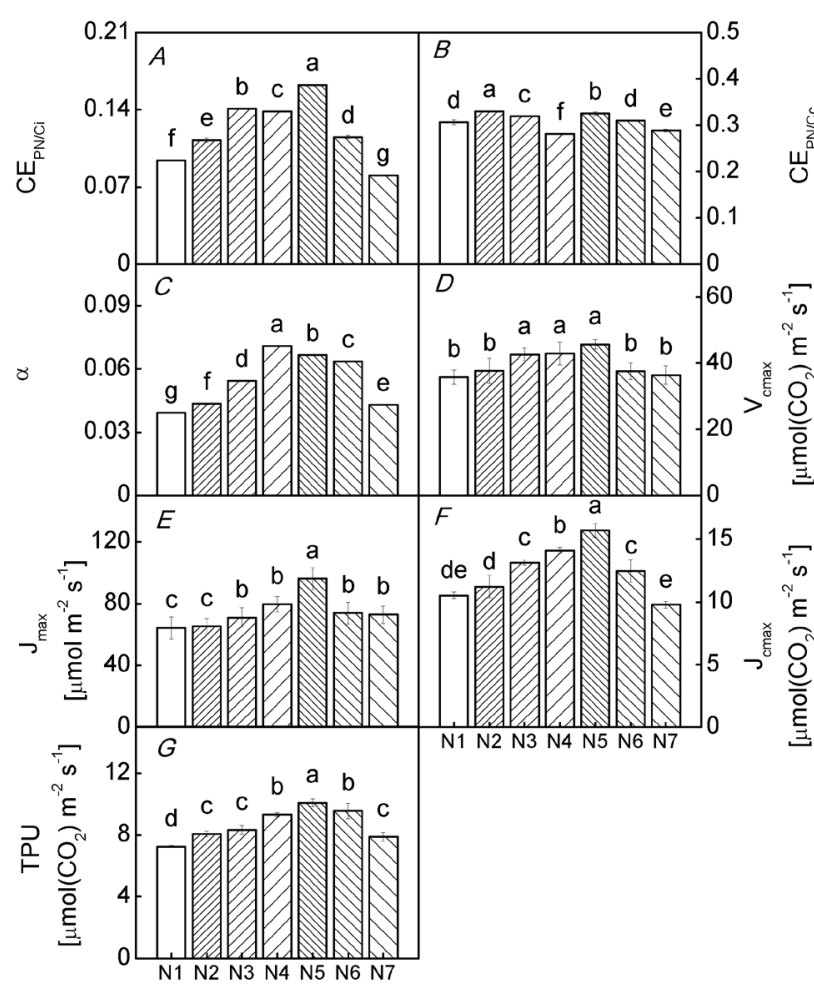

Fig. 2. Effects of different $\mathrm{N}$ levels on carboxylation efficiency calculated from $P_{\mathrm{N}} / C_{\mathrm{i}}$ curves $\left(\mathrm{CE}_{\mathrm{PN} / \mathrm{Ci}}\right)(A)$ and $P_{\mathrm{N}} / C_{\mathrm{c}}$ curves $\left(\mathrm{CE}_{\mathrm{PN} / \mathrm{Cc}}\right)(B)$, apparent quantum yield $(\alpha)(C)$, maximum carboxylation rate limited by Rubisco $\left(\mathrm{V}_{\text {cmax }}\right)(D)$, electron transport rate $\left(\mathrm{J}_{\max }\right)(E)$, RuBP regeneration $\left(\mathrm{J}_{\mathrm{cmax}}\right)(F)$, and triose phos-phate use (TPU) $(G)$ of 'Huangguogan' citrus plants. Data are means \pm SD of three replicates. Significant differences $(P<5 \%)$ between treatments are indicated by different letters. $\mathrm{N}_{1}, \mathrm{~N}_{2}, \mathrm{~N}_{3}, \mathrm{~N}_{4}$, $\mathrm{N}_{5}, \mathrm{~N}_{6}$, and $\mathrm{N}_{7}$ stand for $0,30,60,90,120,150$, and $180 \mathrm{~g}(\mathrm{~N})$ year $^{-1}$, respectively.

that with increasing nitrogen application, $P_{\mathrm{N}}$ and $g_{\mathrm{s}}$ initially increased and then decreased, whereas the response of $C_{\mathrm{i}}$ was the reverse one. Thus, relative to $\mathrm{N}_{1}$, the decrease in $C_{\mathrm{i}}$ caused by an increase in $P_{\mathrm{N}}$ was more significant than the increase in $C_{\mathrm{i}}$ caused by the increase in $g_{\mathrm{s}}$. Consequently, decreases in $C_{\mathrm{i}}$ were noted for $\mathrm{N}_{2}, \mathrm{~N}_{3}$, and $\mathrm{N}_{4}$. In contrast, the decrease in $C_{\mathrm{i}}$ caused by a decrease in $\mathrm{g}_{\mathrm{s}}$ was more significant than the increase in $C_{\mathrm{i}}$ caused by a decrease in $P_{\mathrm{N}}$. Therefore, $C_{\mathrm{i}}$ increased under $\mathrm{N}_{5}, \mathrm{~N}_{6}$, and $\mathrm{N}_{7}$.

Stomatal conductance affects photosynthesis by changing $C_{\mathrm{i}}$ (Arp 1991). We found that the $\mathrm{N}$ application rate increased $g_{\mathrm{s}}$ up to a threshold after which it first leveled and then decreased. The stomatal size decreased with increasing stomatal density (Franks and Beerling 2009). On the other hand, $g_{\mathrm{s}}$ is correlated with the stomatal size, density, and extent of aperture. In the present study, stomatal density decreased significantly with increasing $\mathrm{N}$, while stomatal volume changed only slightly. Therefore, changes in $g_{\mathrm{s}}$ may be due to alterations in stomatal morphology caused by nitrogen content. Thus, the decline in photosynthesis caused by excessive $\mathrm{N}$ supply may, to a certain extent, be the consequence of reduced $g_{s}$.

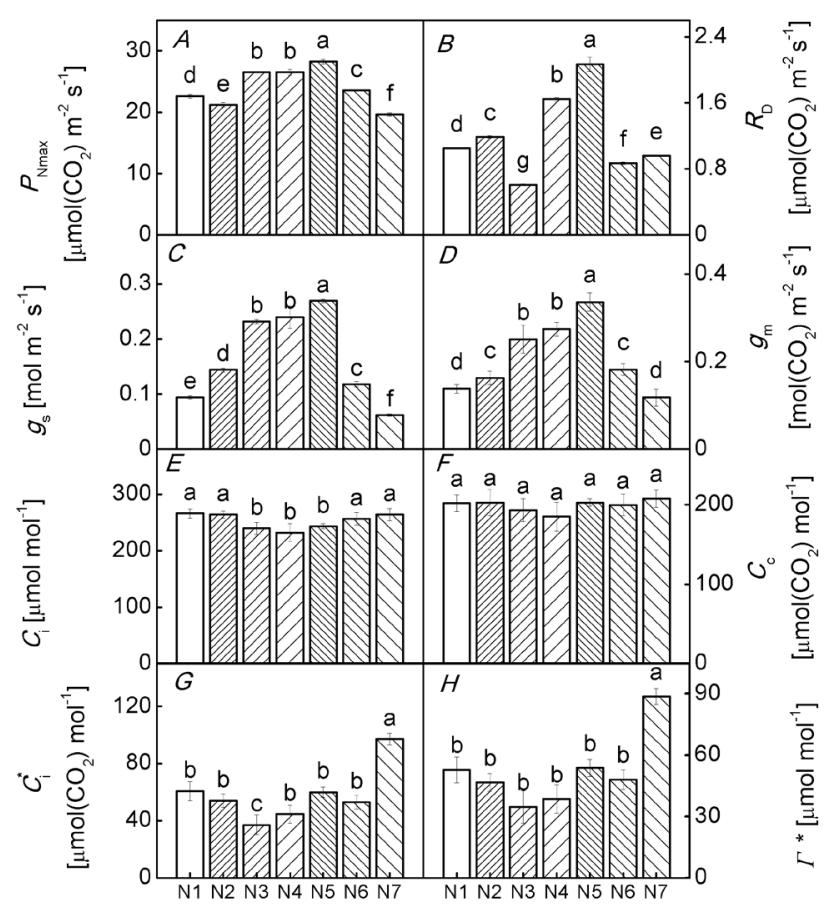

Fig. 3. Effects of different $\mathrm{N}$ levels on light-saturated $\mathrm{CO}_{2}$ assimilation $\left(P_{\mathrm{N} \max }\right)(A)$, day respiration rate $\left(R_{\mathrm{D}}\right)(B)$, stomatal conductance $\left(g_{\mathrm{s}}\right)(C)$, mesophyll conductance $\left(g_{\mathrm{m}}\right)(D)$, intercellular $\mathrm{CO}_{2}$ concentration $\left(C_{\mathrm{i}}\right)(E)$, chloroplastic $\mathrm{CO}_{2}$ concentration $\left(C_{\mathrm{c}}\right)(F), \mathrm{CO}_{2}$-compensation point related to $C_{\mathrm{i}}\left(C_{\mathrm{i}}^{*}\right)(G)$, and $\mathrm{CO}_{2}$ compensation point in the absence of respiration $\left(\Gamma^{*}\right)(H)$. Data are means $\pm \mathrm{SD}$ of five replicates for $C_{\mathrm{c}}$ and $g_{\mathrm{m}}$, and of three replicates for $P_{\mathrm{Nmax}}, R_{\mathrm{D}}, g_{\mathrm{s}}, C_{\mathrm{i}}, C_{\mathrm{i}}^{*}$, and $\Gamma^{*}$. Significant differences $(P<5 \%)$ between treatments are indicated by different letters. $\mathrm{N}_{1}$, $\mathrm{N}_{2}, \mathrm{~N}_{3}, \mathrm{~N}_{4}, \mathrm{~N}_{5}, \mathrm{~N}_{6}$, and $\mathrm{N}_{7}$ stand for $0,30,60,90,120,150$, and $180 \mathrm{~g}(\mathrm{~N})$ year $^{-1}$, respectively.

N supplement improved photosynthesis by enhancing carboxylation and $\mathrm{CO}_{2}$ diffusion: Rubisco content was reported excessively high under relatively large $\mathrm{N}$ supply (Adams 2004). It is also well known that photosynthetic capacity may decline in response to a reduction in Rubisco activity (Wong 1979). Here, we observed significant differences between $\mathrm{N}$ treatments in terms of $\mathrm{CE}_{\mathrm{PN} / \mathrm{Ci}}$ and $\alpha$; further, Rubisco activity was positively correlated with $\mathrm{CE}_{\mathrm{PN} / \mathrm{Ci}}$. Indeed, there were significant differences between $\mathrm{N}$ application rates in terms of $\mathrm{CE}_{\mathrm{PN} / \mathrm{Ci}}$ and $\mathrm{CE}_{\mathrm{PN} / \mathrm{Cc}}$ (Fig. 2); in general, as $\mathrm{N}$ increased, $\mathrm{CE}_{\mathrm{PN} / \mathrm{Ci}}$ and $\mathrm{CE}_{\mathrm{PN} / \mathrm{Cc}}$ tended to increase first and decrease thereafter. Concomitantly, increase in total Rubisco activity was lower than that in leaf N, with increasing N supply (Cheng and Fuchigami 2000). We found that Rubisco activity and leaf $\mathrm{N}$ rapidly decreased, while Rubisco content decreased much more gradually as $\mathrm{N}$ supply increased to the highest doses tested (150 and $180 \mathrm{~g})$.

Gaseous $\mathrm{CO}_{2}$ diffuses through the intercellular space from the inferior stomatal cavity to the mesophyll cell wall surfaces (Flexas et al. 2008). Thus, $\mathrm{CO}_{2}$ concentration at the carboxylation site is apparently lower than it is in the intercellular spaces $\left(C_{\mathrm{c}}<C_{\mathrm{i}}\right)$ (Evans and von Caemmerer 


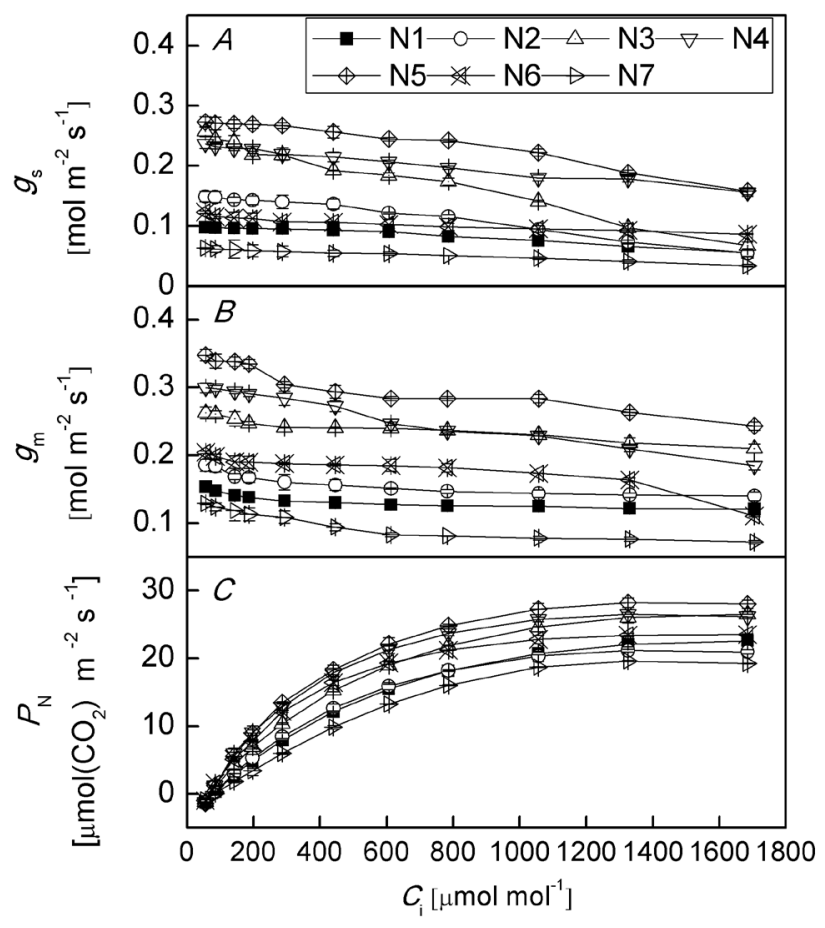

Fig. 4. Effects of $\mathrm{N}$ supplement on stomatal conductance $\left(g_{\mathrm{s}}\right)(A)$, mesophyll conductance $\left(g_{\mathrm{m}}\right)(B)$, and light-saturated $\mathrm{CO}_{2}$ assimilation $\left(P_{\mathrm{N}}\right)(C)$ response to $C_{\mathrm{i}}$. Values are means $\pm \mathrm{SE}$ of five replicates. $\mathrm{N}_{1}, \mathrm{~N}_{2}, \mathrm{~N}_{3}, \mathrm{~N}_{4}, \mathrm{~N}_{5}, \mathrm{~N}_{6}$, and $\mathrm{N}_{7}$ stand for $0,30,60,90$, 120,150 , and $180 \mathrm{~g}(\mathrm{~N})$ year $^{-1}$, respectively.

1996). It was reported that $g_{\mathrm{m}}$ varied with $C_{\mathrm{i}}$ and light level in a manner resembling the responses of stomatal conductance to $\mathrm{CO}_{2}$ and light level changes (Flexas et al. 2007). $\mathrm{CO}_{2}$ assimilation in woody plants may be limited by $g_{\mathrm{m}}$ (Harley et al. 1992, Lawlor 2002). The rapid response of $g_{\mathrm{m}}$ to changes in ambient $\mathrm{CO}_{2}$ concentration and PPFD have been studied (Flexas et al. 2012). Studies have shown that $g_{\mathrm{m}}$ tends to decrease when plants grow in environments with poor $\mathrm{N}$ supply (Warren et al. 2007). There was a positive correlation between leaf $\mathrm{N}$ content and $g_{\mathrm{m}}$ (von Caemmerer and Evans 1991). Our results suggest that with increasing $\mathrm{N}$ application rate, the change trend of $g_{\mathrm{m}}$ was similar to that of leaf $\mathrm{N}$ content; therefore, $\mathrm{N}$ may play a role in the rapid response of $g_{\mathrm{m}}$ to $\mathrm{CO}_{2}$ concentration. Photosynthetic capacity reflects electron

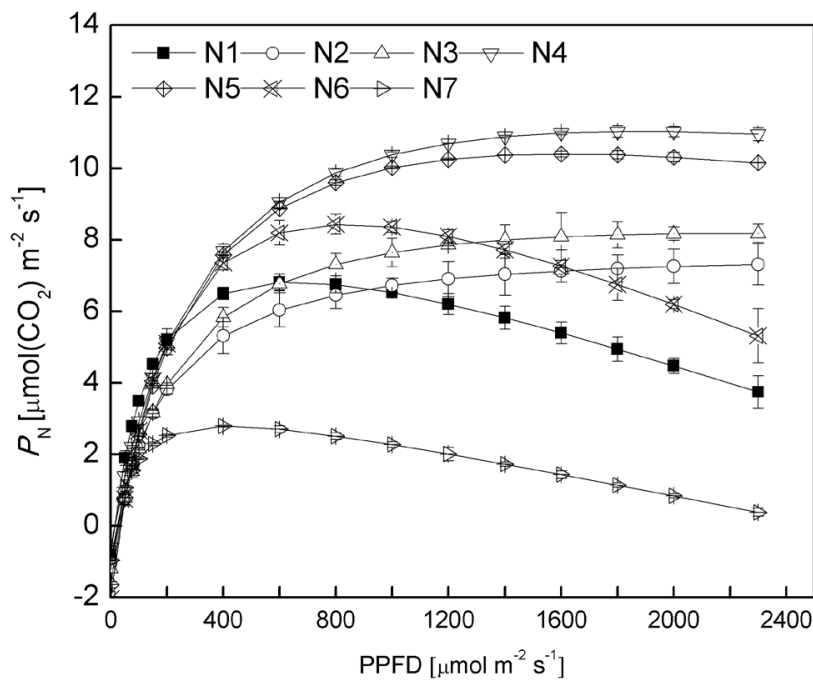

Fig. 5. Effects of $\mathrm{N}$ supplement on photosynthesis $\left(P_{\mathrm{N}}\right)$ response to PPFD. Values are means \pm SE of three replicates. $\mathrm{N}_{1}, \mathrm{~N}_{2}, \mathrm{~N}_{3}, \mathrm{~N}_{4}$, $\mathrm{N}_{5}, \mathrm{~N}_{6}$, and $\mathrm{N}_{7}$ stand for $0,30,60,90,120,150$, and $180 \mathrm{~g}(\mathrm{~N})$ year $^{-1}$, respectively.

transport and phosphorylation activity in plant leaves (Ye 2010). With increasing $\mathrm{N}$ application rate, $P_{\mathrm{N}}$ changed in the same way as $g_{\mathrm{m}}$. Therefore, increasing $\mathrm{N}$ application increased the photosynthetic capacity in plants of cultivar 'Huangguogan,' but excessive N supply actually limited it. Other important indicators of photosynthetic rate are $\mathrm{V}_{\text {cmax }}, \mathrm{J}_{\max }$, and TPU. These parameters help accelerate photosynthate accumulation and, by extension, influence both vegetative and reproductive growth (Wang et al. 2014). The Chl content changed with $\mathrm{N}$ concentration which, in turn, significantly altered the maximum electron transport rate $\left(\mathrm{J}_{\max }\right)$ (Fig. 2). Estimated $\mathrm{V}_{\text {cmax }}$ were 35.74, 45.67, and $36.42 \mu \mathrm{mol}\left(\mathrm{CO}_{2}\right) \mathrm{m}^{-2} \mathrm{~s}^{-1}$ under $\mathrm{N}_{1}, \mathrm{~N}_{5}$, and $\mathrm{N}_{7}$, respectively. When Rubisco was fully activated, optimal Rubisco contents (Rubisco opt) (Farquhar et al. 1980, Li et al. 2009) were $0.24,0.37$, and $0.18 \mathrm{~g} \mathrm{~m}^{-2}$ for $\mathrm{N}_{1}, \mathrm{~N}_{5}$, and $\mathrm{N}_{7}$, respectively. These Rubisco contents corresponded to the requirement of $P_{\mathrm{N}}$ at atmospheric $\mathrm{CO}_{2}$ concentration. Rubisco $_{\text {opt }}$ accounted only for 25,30 , and $18 \%$ of the total Rubisco content under $\mathrm{N}_{1}, \mathrm{~N}_{5}$, and $\mathrm{N}_{7}$, respectively (Fig. 1). Therefore, over $50 \%$ of Rubisco was present in its inactive form. Thus, relatively more of the Rubisco

Table 2. Effects of different $\mathrm{N}$ levels on stomatal density, stomatal major axis, and stomatal minor axis of 'Huangguogan' citrus plants. Data are means \pm SD of ten replicates. Significant differences $(P<5 \%)$ among treatments are indicated by different letters. $\mathrm{N}_{1}, \mathrm{~N}_{2}, \mathrm{~N}_{3}$, $\mathrm{N}_{4}, \mathrm{~N}_{5}, \mathrm{~N}_{6}$, and $\mathrm{N}_{7}$ stand for $0,30,60,90,120,150$, and $180 \mathrm{~g}(\mathrm{~N})$ year ${ }^{-1}$, respectively.

\begin{tabular}{llll}
\hline Treatment & Stomatal density $\left[\right.$ No. $\left.m^{-2}\right]$ & Stomatal major axis $[\mu \mathrm{m}]$ & Stomatal minor axis $[\mu \mathrm{m}]$ \\
\hline $\mathrm{N}_{1}$ & $937.00 \pm 14.00^{\mathrm{a}}$ & $20.99 \pm 0.42^{\mathrm{b}}$ & $15.87 \pm 3.23^{\mathrm{a}}$ \\
$\mathrm{N}_{2}$ & $864.33 \pm 11.68^{\mathrm{b}}$ & $23.95 \pm 1.43^{\mathrm{ab}}$ & $16.42 \pm 2.23^{\mathrm{a}}$ \\
$\mathrm{N}_{3}$ & $718.00 \pm 6.56^{\mathrm{c}}$ & $23.99 \pm 5.09^{\mathrm{a}}$ & $15.89 \pm 3.17^{\mathrm{a}}$ \\
$\mathrm{N}_{4}$ & $567.33 \pm 10.69^{\mathrm{d}}$ & $26.97 \pm 2.49^{\mathrm{a}}$ & $16.08 \pm 7.00^{\mathrm{a}}$ \\
$\mathrm{N}_{5}$ & $533.00 \pm 8.72^{\mathrm{e}}$ & $28.27 \pm 1.05^{\mathrm{a}}$ & $21.45 \pm 3.77^{\mathrm{a}}$ \\
$\mathrm{N}_{6}$ & $506.33 \pm 8.33^{\mathrm{f}}$ & $24.87 \pm 2.57^{\mathrm{a}}$ & $16.05 \pm 2.33^{\mathrm{a}}$ \\
$\mathrm{N}_{7}$ & $488.67 \pm 3.51^{\mathrm{g}}$ & $26.76 \pm 0.54^{\mathrm{a}}$ & $14.37 \pm 2.88^{\mathrm{ab}}$ \\
\hline
\end{tabular}


enzyme present was inactivated under high $\mathrm{N}$ application rates. This transformation may influence $\mathrm{N}$ storage (Manter and Kerrigan 2004, Li et al. 2009). According to the FvCB model, when $C_{\mathrm{i}}$ is low, the photosynthetic rate is determined by $C_{\mathrm{i}}$, and the photosynthetic rate is positively correlated with $\mathrm{V}_{\text {cmax }}$. This association reflects the control of Rubisco over photosynthetic rate. As $C_{\mathrm{i}}$ increases, the photosynthetic rate increase begins to slow down and is gradually limited by RuBP regeneration. When photosynthetic rate no longer increases with increasing $\mathrm{CO}_{2}$, photosynthetic limitation has entered the TPU-restriction stage (Farquhar et al. 1980, Sun et al. 2014, Niinemets et al. 2015). In this study, $\mathrm{J}_{\mathrm{cmax}}$ and $\mathrm{V}_{\mathrm{cmax}}$ were higher than $P_{\mathrm{N}}$ at atmospheric $\mathrm{CO}_{2}$ concentration. Therefore, $C_{\mathrm{c}}$ did not saturate the carboxylation reaction. Elevated $P_{\mathrm{N}}$ in the leaves of cultivar 'Huangguogan' under high $\mathrm{N}$ supply was associated with high mesophyll conductance and chloroplast $\mathrm{CO}_{2}$ concentration. However, these results also indicate that excessive $\mathrm{N}$ supply lowered Rubisco activity and content, $\mathrm{CE}, g_{\mathrm{m}}$, and $C_{\mathrm{c}}$, all of which together eventually led to a decrease in $P_{\mathrm{N}}$.

Conclusions: The aim of this study was to elucidate the effects of $\mathrm{N}$ supply on photosynthesis. We confirmed that photosynthetic rate is positively correlated with leaf $\mathrm{N}$ and Rubisco content. The photosynthetic rate of leaves of cultivar 'Huangguogan' increased with increasing $\mathrm{N}$ up to an optimal supply level of $120 \mathrm{~g}$ per year, but decreased thereafter with increasing $N$. Our results suggest that limitation of the photosynthetic capacity of cultivar 'Huangguogan' was correlated with the decrease of $g_{\mathrm{m}}$, $C_{c}$, and Rubisco content and activity caused by excess $\mathrm{N}$ supply. The ultimate purpose and advantage of assessing the comparative effects of various $\mathrm{N}$ contents on photosynthetic performance are related to optimizing the yield and quality of cultivar 'Huangguogan.' Our study can thus contribute to a better understanding of the photosynthetic capacity response to nitrogen supply and can provide a reference for the rational application of nitrogen fertilizer in orchards of the hybrid citrus cultivar 'Huangguogan.'

\section{References}

Adachi S., Nakae T., Uchida M. et al.: The mesophyll anatomy enhancing $\mathrm{CO}_{2}$ diffusion is a key trait for improving rice photosynthesis. - J. Exp. Bot. 64: 1061-1072, 2013.

Adams M.A.: Evergreen trees do not maximize instantaneous photosynthesis. - Trends Plant Sci. 9: 270-274, 2004.

Albertsson P.: A quantitative model of the domain structure of the photosynthetic membrane. - Trends Plant Sci. 6: 349-354, 2001.

Arp W.J.: Effects of source-sink relations on photosynthetic acclimation to elevated $\mathrm{CO}_{2}$. - Plant Cell Environ. 14: 869-875, 1991.

Barbet-Massin C., Giuliano S., Alletto L. et al.: Nitrogen limitation alters biomass production but enhances steviol glycoside concentration in Stevia rebaudiana Bertoni. - PLoS ONE 10: e0133067, 2015.

Barbour M.M., Kaiser B.N.: The response of mesophyll conductance to nitrogen and water availability differs between wheat genotypes. - Plant Sci. 251: 119-127, 2016.
Bondada B.R., Syvertsen J.P.: Leaf chlorophyll, net gas exchange and chloroplast ultrastructure in citrus leaves of different nitrogen status. - Tree Physiol. 23: 553-559, 2003.

Brown R.H. , Byrd G. T. , Black C. C.: Assessing the degree of $\mathrm{C} 4$ photosynthesis in C3-C4 species using an inhibitor of phosphoenolpyruvate carboxylase. - Plant Physiol. 97: 985989,1991.

Buckley T.N., Warren C.R.: The role of mesophyll conductance in the economics of nitrogen and water use in photosynthesis. Photosynth. Res. 119: 77-88, 2014.

Chang S.X., Robison D.J.: Nondestructive and rapid estimation of hardwood foliar nitrogen status using the SPAD-502 chlorophyll meter. - Forest Ecol. Manag. 181: 331-338, 2003.

Chen W., Su Z., Qian T. et al.: [Comparative study of stomatal density and gas diffusion resistance in leaves of various types of rice.] - Korean J. Crop Sci. 40: 25-132, 1995. [In Korean]

Cheng L., Fuchigami L.H.: Rubisco activation state decreases with increasing nitrogen content in apple leaves. - J. Exp. Bot. 51: 1687-1694, 2000.

Cruz J.L., Mosquim P.R., Pelacani C.R. et al.: Photosynthesis impairment in cassava leaves in response to nitrogen deficiency. - Plant Soil 257: 417-423, 2003.

Esteban R., García-Plazaola J.I., Hernández A. et al.: On the recalcitrant use of Arnon's method for chlorophyll determination. - New Phytol. 217: 474-476, 2017.

Evans J.R., Kaldenhoff R., Genty B., Terashima I.: Resistances along the $\mathrm{CO}_{2}$ diffusion pathway inside leaves. - J. Exp. Bot. 60: 2235-2248, 2009.

Evans J.R., von Caemmerer S.: Carbon dioxide diffusion inside leaves. - Plant Physiol. 110: 339-346, 1996.

Farquhar G.D., von Caemmerer S., Berry J.A.: A biochemical model of photosynthetic $\mathrm{CO}_{2}$ assimilation in leaves of $\mathrm{C}_{3}$ species. - Planta 149: 78-90, 1980.

Flexas J., Barbour M.M., Brendel O. et al.: Mesophyll diffusion conductance to $\mathrm{CO}_{2}$ : An unappreciated central player in photosynthesis. - Plant Sci. 193-194: 70-84, 2012.

Flexas J., Diaz-Espejo A., Galmés J. et al.: Rapid variations of mesophyll conductance in response to changes in $\mathrm{CO}_{2}$ concentration around leaves. - Plant Cell Environ. 30: 1284-1298, 2007.

Flexas J., Ribas-Carbó M., Diaz-Espejo A. et al.: Mesophyll conductance to $\mathrm{CO}_{2}$ : Current knowledge and future prospects. Plant Cell Environ. 31: 602-621, 2008.

Flexas J., Ribas-Carbó M.: Analysis of leakage in IRGA's leaf chambers of open gas exchange systems: Quantification and its effects in photosynthesis parameterization. - J. Exp. Bot. 58: 1533-1543, 2007.

Franks P.J., Beerling D.J.: Maximum leaf conductance driven by $\mathrm{CO}_{2}$ effects on stomatal size and density over geologic time. P. Natl. Acad. Sci. USA 106: 10343-10347, 2009.

Guo S., Zhou Y., Shen Q., Zhang F.: Effect of ammonium and nitrate nutrition on some physiological processes in higher plants - growth, photosynthesis, photorespiration, and water relations. - Plant Biol. 9: 21-29, 2007.

Harley P.C., Loreto F., Di Marco G., Sharkey T.D.: Theoretical considerations when estimating the mesophyll conductance to $\mathrm{CO}_{2}$ flux by analysis of the response of photosynthesis to $\mathrm{CO}_{2}$.Plant Physiol. 98: 1429-1436, 1992.

Hynniewta M., Malik S.K., Rao S.R.: Genetic diversity and phylogenetic analysis of Citrus (L) from north-east India as revealed by meiosis, and molecular analysis of internal transcribed spacer region of rDNA. - Meta Gene 2: 237-251, 2014.

Jiang C.D., Wang X., Gao H.Y. et al.: Systemic regulation of leaf anatomical structure, photosynthetic performance, and highlight tolerance in sorghum. - Plant Physiol. 155: 1416-1424, 
2011.

Laĭsk A.K.: [Kinetics of photosynthesis and photorespiration of $\mathrm{C}_{3}$ in plants.] Pp. 13-128. Nauka, Moscow 1977. [In Russian]

Lawlor D.W.: Limitation to photosynthesis in water-stressed leaves: Stomata vs. metabolism and the role of ATP. - Ann. Bot. 89: 871-885, 2002

Li H.B., Li Q.Y., Chen W.F. et al.: [Effect of different nitrogen treatments on stomatal density and other physiological characters in rice leaves.] - J. Shenyang Agricultural University 34: 340-343, 2003. [In Chinese]

Li Y., Gao Y., Xu X. et al.: Light-saturated photosynthetic rate in high-nitrogen rice (Oryza sativa L.) leaves is related to chloroplastic $\mathrm{CO}_{2}$ concentration. - J. Exp. Bot. 60: 2351-2360, 2009.

Li Y., Yang X., Ren B. et al.: Why nitrogen use efficiency decreases under high nitrogen supply in rice (Oryza sativa L.) seedlings. - J. Plant Growth Regul. 31: 47-52, 2012.

Makino A., Sato T., Nakano H., Mae T.: Leaf photosynthesis, plant growth and nitrogen allocation in rice under different irradiances. - Planta 203: 390-398, 1997.

Manter D.K., Kerrigan J.: A/ $C_{\mathrm{i}}$ curve analysis across a range of woody plant species: Influence of regression analysis parameters and mesophyll conductance. - J. Exp. Bot. 55: 2581-2588, 2004.

Marcus Y., Altman-Gueta H., Snir A. et al.: Does Rubisco limit the rate of photosynthesis? - In: Allen J.F., Gantt E., Golbeck J.H., Osmond B. (ed.): Photosynthesis. Energy from the Sun. Pp. 863-866. Springer, Dordrecht 2008.

Mauromicale G., Ierna A., Marchese M.: Chlorophyll fluorescence and chlorophyll content in field-grown potato as affected by nitrogen supply, genotype, and plant age. Photosynthetica 44: 76-82, 2006.

Nageswara Rao R.C., Talwar H.S., Wright G.C.: Rapid assessment of specific leaf area and leaf nitrogen in peanut (Arachis hypogaea L.) using a chlorophyll meter. - J. Agron. Crop Sci. 186: 175-182, 2010.

Niinemets Ü., Keenan T.F., Hallik L.: A worldwide analysis of within-canopy variations in leaf structural, chemical and physiological traits across plant functional types. - New Phytol. 205: 973-993, 2015.

Ookawa T., Naruoka Y., Sayama A., Hirasawa T.: Cytokinin effects on ribulose-1,5-bisphosphate carboxylase/oxygenase and nitrogen partitioning in rice during ripening. - Crop Sci. 44: 2107-2115, 2004

Sharkey T.D.: Estimating the rate of photorespiration in leaves. -
Physiol. Plantarum 73: 147-152, 1988.

Sun M.H., Lu X.P., Li J. et al.: [Effect of different nitrogen forms on seedling growth characteristics of citrange.] - Hubei Agricultural Sciences 55: 2014-2018, 2016. [In Chinese]

Sun Y., Gu L., Dickinson R.E. et al.: Impact of mesophyll diffusion on estimated global land $\mathrm{CO}_{2}$ fertilization. - P. Natl. Acad. Sci. USA 111: 15774-15779, 2014.

von Caemmerer S., Evans J.R.: Determination of the average partial pressure of $\mathrm{CO}_{2}$ in chloroplasts from leaves of several $\mathrm{C}_{3}$ plants. - Funct. Plant Biol. 18: 287-305, 1991.

von Caemmerer S., Evans J.R.: Enhancing $C_{3}$ photosynthesis. Plant Physiol. 154: 589-592, 2010.

Vu J.C.V.: Photosynthesis, growth, and yield of citrus at elevated atmospheric $\mathrm{CO}_{2}$. - J. Crop Im. 13: 361-376, 2005.

Wang H.Z., Han L., Xu Y.L. et al.: [Photosynthetic responses of the heteromorphic leaves in Populus euphratica to light intensity and $\mathrm{CO}_{2}$ concentration.] - Chin. J. Plant Ecol. 38: 1099-1109, 2014. [In Chinese]

Warren C.R., Löw M., Matyssek R., Tausz M.: Internal conductance to $\mathrm{CO}_{2}$ transfer of adult Fagus sylvatica: Variation between sun and shade leaves and due to free-air ozone fumigation. - Environ. Exp. Bot. 59: 130-138, 2007.

Wong S.C.: Elevated atmospheric partial pressure of $\mathrm{CO}_{2}$ and plant growth. I. Interactions of nitrogen nutrition and photosynthetic capacity in $\mathrm{C}_{3}$ and $\mathrm{C}_{4}$ plants. - Oecologia 44: 68-74, 1979.

Xiong B., Ye S., Qiu X. et al:: Transcriptome analyses of two Citrus cultivars (Shiranuhi and Huangguogan) in seedling etiolation. - Sci. Rep.-UK 7: 46245, 2017.

Xiong D., Yu T., Zhang T. et al.: Leaf hydraulic conductance is coordinated with leaf morpho-anatomical traits and nitrogen status in the genus Oryza. - J. Exp. Bot. 66: 741-748, 2015.

Yamori W., Nagai T., Makino A.: The rate-limiting step for $\mathrm{CO}_{2}$ assimilation at different temperatures is influenced by the leaf nitrogen content in several $\mathrm{C}_{3}$ crop species. - Plant Cell Environ. 34: 764-777, 2011.

Yan F., Sun Y., Song F., Liu F.: Differential responses of stomatal morphology to partial root-zone drying and deficit irrigation in potato leaves under varied nitrogen rates. - Sci. Hortic.Amsterdam 145: 76-83, 2012.

Ye Z.P.: [A review on modeling of responses of photosynthesis to light and $\mathrm{CO}_{2}$.] - Chin. J. Plant Ecol. 34: 727-740, 2010. [In Chinese]

Zekri M., Obreza T.A.: Plant Nutrients for Citrus Trees. SL 200. Pp. 1-5. Soil and Water Science Department, UF/IFAS Extension, Gainesville 2015.

(C) The authors. This is an open access article distributed under the terms of the Creative Commons BY-NC-ND Licence. 